\title{
Drying kinetics and determination of water sorption isotherms of corn
}

\author{
J. Roy ${ }^{1,2}$, M. A. Alim ${ }^{1}$ and M. N. Islam ${ }^{1}$ \\ ${ }^{1}$ Department of Food Technology and Rural Industries, Bangladesh Agricultural University Mymensingh-2202, Bangladesh \\ ${ }^{2}$ Department of Food Engineering and Technology, Hajee Mohammad Danesh Science and Technology University, Dinajpur
}

\begin{tabular}{|c|c|}
\hline ARTICLE INFO & Abstract \\
\hline $\begin{array}{l}\text { Article history: } \\
\text { Received: } 17 \text { May } 2017 \\
\text { Accepted: } 19 \text { November } 2017\end{array}$ & \multirow{3}{*}{$\begin{array}{l}\text { The study was carried out for the purpose of determining the drying kinetics as well as moisture sorption } \\
\text { isotherm of hybrid- } 81 \text { corn. Corn at about } 31 \% \text { moisture content }(\mathrm{wb}) \text { was dried in a forced convective hot } \\
\text { air cabinet dryer at different drying conditions, such as variable air dry bulb temperature }\left(40^{\circ} \mathrm{C}, 50^{\circ} \mathrm{C} \text { and }\right. \\
\left.60^{\circ} \mathrm{C}\right) \text { and loading density }\left(3.56 \mathrm{~kg} / \mathrm{m}^{2}, 7.12 \mathrm{~kg} / \mathrm{m}^{2} \text {, and } 10.68 \mathrm{~kg} / \mathrm{m}^{2}\right) \text { as well as in shining sun at different } \\
\text { layers }\left(3.56 \mathrm{~kg} / \mathrm{m}^{2}, 7.12 \mathrm{~kg} / \mathrm{m}^{2}, \text { and } 10.68 \mathrm{~kg} / \mathrm{m}^{2}\right) \text {. The water sorption isotherm of the dried corn was } \\
\text { developed using vacuum desiccators, which contained saturated salt solutions in the range of } 11-93 \% \\
\text { RHs. The mono-layer moisture content calculated by the Brunauer-Emmett-Teller (BET) model }(6.76 \\
\mathrm{g} / 100 \mathrm{~g} \text { solid) was lesser than that calculated by the Guggenheim-Anderson-De Boer }(\mathrm{GAB}) \text { model } \\
(10.53 \mathrm{~g} / 100 \mathrm{~g} \text { solid). The energy constants were } 10.45 \text { and } 4.64 \text { as per BET and GAB equation, } \\
\left.\text { respectively. Both models gave suitable fits for corn. The activation energy (Ea } \mathrm{E}_{\mathrm{a}}\right) \text { for diffusion of water was } \\
\text { found to be } 11.09 \mathrm{kcal} / \mathrm{gm}-\mathrm{mole} \text { for corn. Furthermore, it was noticed that, with the increase of corn layer, } \\
\text { the drying rate decreased in case of both sun and mechanical drying. However, higher loading density } \\
\text { resulted in efficient drying, at least up to } 10.7 \mathrm{~kg} / \mathrm{m}^{2} \text {. It was shown that the drying time to obtain stability } \\
\text { was the lowest for moisture content }(12.08 \%) \text { corresponding to } \mathrm{a}_{\mathrm{w}} \text { of } 0.65 \text { in case of BET or GAB } \\
\text { monolayer moisture content. This finding could be helpful in predicting the storage life of corn. }\end{array}$} \\
\hline $\begin{array}{l}\text { Keywords: } \\
\text { Corn, Drying Kinetics, Sorption } \\
\text { Behavior, Activation Energy, BET, } \\
\text { GAB }\end{array}$ & \\
\hline $\begin{array}{l}\text { Correspondence: } \\
\text { J. Roy } \\
\text { ( joysree.tithi.18@gmail.com ) }\end{array}$ & \\
\hline
\end{tabular}

\section{Introduction}

Maize has been being cultivated since the ancient time as it is the most productive crop species. Over the past few decades, maize has emerged as a major economic crop in the world (Jyoti and Takhar, 2010). The major production regions (Kim and Dale, 2004) are North America (42\%), Asia (26\%), Europe (12\%) and South America (9\%). It constitutes a staple food in many countries all over the world. Nutritional value of corn is normal like any other cereals. Its grain contains $11.2 \%$ protein, $66.2 \%$ carbohydrate, $3.6 \%$ fat, $1.5 \%$ minerals and $2.7 \%$ fibre (Gopalan et al., 1981). Additionally, it contains $90 \mathrm{mg}$ carotene, $1.18 \mathrm{mg}$ niacin, $0.8 \mathrm{mg}$ thiamine and $0.1 \mathrm{mg}$ riboflavin per $100 \mathrm{~g}$ grains.

Corn is an important industrial raw material in the starch industry (Doymaz and Pala, 2003). Corn can be consumed directly as green cob, roasted cob or popped grain and flour satu. It is also used for manufacturing alcohol, corn flakes, salad oil, soap varieties, paints and similar products. At harvest time, maize has a moisture content too high to be stored (between $30 \%$ and $40 \%$ wb), and has to be dried. After harvesting, drying of maize in Bangladesh is normally done by spreading the product under sun. Although sun drying offers a cheap method, it often results in inferior quality due to environmental contaminants, such as dust and insects, pests and microorganisms. In the mechanical dryer, desired temperature and airflow can be maintained compared to sun/solar drying. As a result, higher production rate and improved quality products can be achieved in mechanical drying. Moreover, mechanical drying is independent of sunlight and can be used when necessary. There are a number of mechanical dryers of which cabinet drying system is a moderately cheap and excellent system for producing good quality dried seeds.

During drying and storage, physical and chemical properties of agricultural products can change. The main reasons for these changes are moisture content of materials, relative humidity of the surrounding air, and drying and storage conditions. The relationship between equilibrium relative humidity (ERH) and equilibrium moisture content (EMC) is normally defined by moisture sorption isotherms. Sorption properties of foods (EMC and monolayer moisture) are essential for the design, modeling and optimization of many processes such as drying, packaging and storage (Al-Muhtaseb et al., 2002). Sorption isotherm is the plot of equilibrium moisture content of a material subjected to different relative humilities at a given temperature in closed environment and is required to determine end point of drying.

The water sorption in foods is a very complex phenomenon consisting of several different mechanisms that depend on the material structure and composition (Staudt et al., 2013). As a consequence, a number of models have been proposed for describing moisture sorption isotherm (Chen and Weng, 2010), including theoretical models based on a monolayer (BET model), theoretical models based on a multi-layer and condensed 
film (GAB model), semi-empirical (Ferro-Fontan, Henderson and Halsey models) and empirical models (Smith and Oswin models). However, there is no unique model that can describe sorption characteristics of a particular application. Different results may be obtained depending on the model(s) used for sorption isotherms. It is, therefore, difficult to answer which model is suitable for what kind of application. Therefore, comparison and testing of different models for various applications are necessary to select the best one. However, the main advantage of theoretical models over the empirical and semi-empirical ones is the fact that their parameters have physical meaning. For instance, BET and GAB equations include the monolayer moisture content that constitutes very important information since is it directly related to the shelf life and stability of foods. The BET monolayer concept was found to be a reasonable guide with respect to various aspects of interest in dried foods (Timmermann et al., 2001). On the other side, GAB model is considered to be the most versatile sorption model to fit the sorption data for all foods. Both BET and GAB have been widely used in the literature for a variety of products (Mcmin and Magee, 2003).

With bright market potential, the area planted with corn increased dramatically in the last few years. Producers need to dry corn to $15.5 \%$ moisture content (MC) when corn is to be marketed immediately. Other wise, corn needs to be dried to $12.0 \% \mathrm{MC}$ if it is expected to be stored for several months. Considering the above discussions, an approach was made to dry corn at different temperature and time combinations to determine the dying kinetics as well as water sorption isotherms of corn. The specific objectives were to study the drying kinetics (i) to determine the drying parameters for optimum drying, (ii) to determine the sorption characteristics of corn using BET and GAB equations and (iii) to determine the drying time to obtain the stability of the product.

\section{Materials and Methods}

Fresh corn was collected from the farmers of Gaibandha district during harvesting time. Husks were removed from corn. Kernels from the cob were also separated manually.

\section{Drying methods}

Mechanical drying: Forced convection hot air type cabinet dryer was used for drying corn. The dryer consists of several chambers in which trays of samples were placed. Fresh corns of known moisture content and loading density were placed in trays and drying commenced in the drier at constant air velocity and air dry bulb temperature. The velocity of air was measured $(0.6 \mathrm{~m} / \mathrm{sec}$.) by anemometer. Air was blown by a fan passing through a heater, then across the tray of products being dried from both sides. Weight loss was used as a measure of extent of drying and samples were dried until it came to the equilibrium condition. To determine the effect of temperature, loading density on diffusion coefficients or drying rate, the corn samples were dried at $40^{\circ} \mathrm{C}, 50^{\circ} \mathrm{C}$ and $60^{\circ} \mathrm{C}$ using different loading density such as $3.56 \mathrm{~kg} / \mathrm{m}^{2}, 7.12 \mathrm{~kg} / \mathrm{m}^{2}$, and $10.68 \mathrm{~kg} / \mathrm{m}^{2}$ for single, double and triple layer, respectively.

Sun drying: Corn was evenly spread on tray and kept outside when the sun was shining. In a single layer, 3.56 $\mathrm{kg}$ of corn; in double layer, $7.12 \mathrm{~kg}$ corn; and in triple layer, $10.68 \mathrm{~kg}$ corn was spread in 1 square meter area. After every hour, the corn was collected and weighed, and again spread on the tray for drying as long as bright sunlight was available.

\section{Theoretical consideration and drying kinetics analysis}

Grain drying generally occurs under falling rate period and diffusion is considered as the most likely physical mechanism governing the moisture movement (Saravacos and Raouzeos, 1986). Fick's second law of diffusion can be simplified for describing mass transfer during drying since food dehydration is assumed to be taken place by diffusion process. The solution of the diffusion equation for homogeneous sphere-shaped bodies, such as grain with constant diffusion coefficient, given by Crank (1975) and Islam (1980) is:

$M R=\frac{M_{t}-M_{e}}{M_{0}-M_{e}}=\frac{6}{\pi^{2}} \sum_{n=0}^{\alpha} \operatorname{Exp} \cdot\left[\frac{-(2 n+1)^{2} \pi^{2} D_{e} t}{r^{2}}\right] \ldots$.

For low $\mathrm{M}_{\mathrm{e}}$ values and when the drying time is large, Eq. (1) can be reduced to the following form (Brooker $e t$ al., 1992).

$M R=\frac{M_{t}}{M_{0}}=\frac{6}{\pi^{2}} e \frac{-\pi^{2} D_{e} t}{r^{2}}=\frac{6}{\pi^{2}} e^{-m t}$

where, $\mathrm{m}=\frac{\pi^{2} \mathrm{D}_{\mathrm{e}}}{\mathrm{r}^{2}}=$ drying rate constant, $\mathrm{sec}^{-1}$

$$
\frac{\ln \mathrm{M}_{\mathrm{t}}}{\mathrm{M}_{0}}=\frac{\ln 6}{\pi^{2}}-\mathrm{mt}
$$

where $D_{e}$ is the moisture diffusivity $\left(\mathrm{m}^{2} / \mathrm{s}\right), t$ is the drying time (s) and $r$ is the radius $(m)$. The effective moisture diffusivity $\left(\mathrm{D}_{\mathrm{e}}\right)$ can be calculated from the slope of plot of $\ln (\mathrm{MR})$ against drying time (t).

The diffusion coefficient, $D_{e}$ has an Arrhenius type relationship with drying air dry bulb temperature (abs). The relationship is as follows (Islam, 1980):

$$
\frac{\mathrm{d}_{\ln \mathrm{D}_{\mathrm{e}}}}{\mathrm{dT}_{\mathrm{abs}}}=\frac{\mathrm{E}_{\mathrm{a}}}{\mathrm{RT}_{\mathrm{abs}}^{2}} \text { or } \ln \mathrm{D}_{\mathrm{e}}=\ln \mathrm{D}_{0}-\frac{\mathrm{E}_{\mathrm{a}}}{\mathrm{RT}_{\mathrm{abs}}} \ldots \ldots . .(4)
$$

where $D_{e}=$ the constant of integration, and is usually referred to a frequency factor when discussing Arrhenius 
equation. $E_{a}=$ activation energy of diffusion of water, cal/g-mole, $\mathrm{R}=$ gas constant, cal $/ \mathrm{g}$-mole, ${ }^{\circ} \mathrm{K}, \mathrm{T}_{\mathrm{abs}}=$ absolute temperature, ${ }^{\circ} \mathrm{K}$. The activation energy can be calculated from the slope of diffusion co-efficient $\left(D_{\mathrm{e}}\right)$ versus the inverse absolute temperature.

\section{Determination of sorption isotherm}

There are several different methods to determine the sorption isotherms of food materials (Rahman and Sablani, 2009). Many authors preferred gravimetric static methods using saturated salt solution (SSS) wherein a sample of known mass is stored in an enclosure, such as a desiccator, and is allowed to reach equilibrium with the surrounding atmosphere of known RH maintained by the solutions. The sample is weighed at regular intervals until a constant weight is reached, which is assumed to be the equilibrium point (Gokhan $e t$ al., 2012).

According to Labuza (1975), the vacuum desiccator method is the most favored method for the determination of the sorption isotherm. In this experiment, this technique was applied. The moisture sorption properties of dried corn were determined at room temperature under conditions of various water activities (0.11-0.93) in the vacuum desiccators using saturated salt solutions. Petridishes were used for preparing salt solution. The various salts were put in the petridish and water was added to give a saturated solution. The method involved putting a small accurately weighed $3 \mathrm{~g}$ sample in a previously weighed crucible in a desiccator, maintained at a known relative humidity by the saturated salt solutions. The desiccators were evacuated. At various intervals, the vacuum was broken and then re-evacuated. The sample was weighed until a constant weight is obtained. The moisture content of the sample was then determined. The following salt solutions of known water activity (Table 1) were used (Islam, 1980).

Table 1. Water activity of saturated salt solution

\begin{tabular}{cc}
\hline Salt & Water activity \\
\hline $\mathrm{LiCl}$ & 0.11 \\
$\mathrm{KC}_{2} \mathrm{H}_{3} \mathrm{O}_{2}$ & 0.20 \\
$\mathrm{MgCl}_{2} \cdot 6 \mathrm{H}_{2} \mathrm{O}$ & 0.33 \\
$\mathrm{~K}_{2} \mathrm{CO}_{3}$ & 0.44 \\
$\mathrm{Mg}\left(\mathrm{NO}_{3}\right)_{2} \cdot 6 \mathrm{H}_{2} \mathrm{O}$ & 0.52 \\
$\mathrm{CaCl}$ & 0.68 \\
$\mathrm{NaCl}$ & 0.75 \\
$\mathrm{KCl}$ & 0.85 \\
$\mathrm{KNO}_{3}$ & 0.93 \\
\hline
\end{tabular}

\section{Sorption isotherm models}

The data obtained corresponding to the $\mathrm{a}_{\mathrm{w}}$ and moisture content was adjusted to BET (Brunauer et al., 1938) and GAB (Anderson, 1946; De Boer, 1953; Guggenheim, 1966) equations in order to determine the best fit.

\section{The BET isotherm}

The Brunauer-Emmett-Teller (BET) sorption model (Brunauer et al., 1938) was used to analyze sorption behavior of corn and thus to obtain the monolayer value and energy constant. The BET equation is:

$\frac{a_{w}}{\left(1-a_{w}\right) m}=\frac{1}{m_{0} C}+\frac{C-1}{m_{0} C} a_{w}$

where $\mathrm{m}=$ the measured moisture at water activity $\left(a_{w}\right)$, $\mathrm{m}_{\mathrm{o}}=$ the monolayer moisture content (the optimal moisture content for maximum storage stability of a dry food) and $\mathrm{C}=$ the isotherm temperature dependence coefficient (energy constant).

\section{The GAB isotherm}

GAB model (Guggenheim-Anderson-DeBoer) is one of the widely used models for describing the sorption data, especially at higher water activities. The GAB model has a similar form as of BET but has an additional parameter $\mathrm{k}$, which is the measure of the difference of free enthalpy (standard chemical potential) of the sorbate molecules that occur in layers above monolayer and in a pure liquid (Timmermann, 2003). This improves the range of applicability for $\mathrm{GAB}$ model in comparison with BET. The GAB model is expressed as follows:

$$
\frac{w}{w_{a}}=\frac{C k a_{w}}{\left(1-k a_{w}\right)\left(1-k a_{w}+C k a_{w}\right)}
$$

where $\mathrm{w}$ is the equilibrium moisture content and $\mathrm{w}_{\mathrm{a}}$ is the monolayer moisture content, both generally expressed in dry basis ( $\mathrm{kg}$ water $/ \mathrm{kg} \mathrm{db}), \mathrm{C}$ is an energetic constant also called as Guggenheim constant, and $\mathrm{k}$ is a parameter that takes into account the difference of chemical potential between the multilayer and bulk water in the food (Timmermann et al., 2001).

The following procedure is suggested by Bizot (1983) to fit data on water activities and equilibrium moisture content. Equation (6) can be transformed as follows:

$$
\begin{gathered}
\frac{a_{w}}{w}=\alpha a_{w}^{2}+\beta a_{w}+\gamma \\
\text { where } \quad \alpha=\frac{k}{w_{m}}\left(\frac{1}{C}-1\right), \beta=\frac{1}{w_{m}}\left(1-\frac{2}{C}\right) \\
\quad \text { and } \gamma=\frac{1}{w_{m} C k}
\end{gathered}
$$

Equation (7) indicates that GAB equation is a threeparameter model. The water activity and equilibrium moisture content are regressed using equation (7) and values of the three coefficients $\alpha, \beta$ and $\gamma$ are obtained. From these coefficients, the values of $\mathrm{k}, \mathrm{w}_{\mathrm{m}}$ and $\mathrm{C}$ can be obtained.

\section{Results and Discussion}

\section{Sorption isotherm behavior of corn}

The water sorption isotherm of dried corn was developed using vacuum desiccators containing saturated salts solution of various water activity (0.11- 
0.93). In this study sorption isotherm of dried corn was established to determine how the corn will behave in a confined environment. Water sorption behavior of corn is shown in Fig. 1. It is seen that EMC value increases with increase in relative humidity. From Fig. 1, it was indicated that the samples absorb little water at particularly lower $\mathrm{a}_{\mathrm{w}}(<0.52)$ and at higher water activity (>0.52) considerable absorption takes place. It is well established that air dried products may be dried to moisture content corresponding to $\mathrm{a}_{\mathrm{w}}$ of 0.60 or 0.65 to be stored for either infinite or 1-2 years in water proof packaging materials/structures, respectively (Nickerson and Sinskey, 1977). It was seen that water content corresponding to water activity of 0.6 and 0.65 was $10.78 \%$ and $12.08 \%$, respectively. The later moisture content (i.e. $12.08 \%$ ) corresponding to $0.65 \mathrm{a}_{\mathrm{w}}$ is generally quoted as the stable moisture content of cereal grains.

\section{Modelling of moisture sorption isotherms}

The monolayer moisture content was estimated using BET and GAB equations. The BET equation is only valid for $\mathrm{a}_{\mathrm{w}}$ below 0.5 (Boquet et al., 1978). Only the $\mathrm{a}_{\mathrm{w}}$ data below this range were adopted to calculate the monolayer moisture value. On the other hand, GAB model is a semi-theoretical multi-molecular localized homogeneous adsorption model and has been considered the best fit model for many food materials over a wide range of $a_{w}$. Modelling of sorption data of corn using BET and GAB equations allows the determination of monolayer moisture content values, which are the measures of sorption possibility of the food material. The prediction of $\mathrm{m}_{\mathrm{o}}$ values is important since deterioration of foods is very small below $\mathrm{m}_{\mathrm{o}}$, since water is strongly bound to the food below $\mathrm{m}_{\mathrm{o}}$ and is not involved in any deteriorative reaction either as solvent or as one of the substrates (Kaymak-Ertekin and Gedik, 2004).

The monolayer moisture content of dried corn calculated from the BET and GAB equations is presented in Table 2 , and graphical presentations of (a) BET equation and (b) GAB model for sorption isotherm of corn are shown in Fig. 2. The monolayer moisture contents calculated from the BET and GAB models were $0.0676 \mathrm{~g} / \mathrm{g}$ (dry basis) and $0.1059 \mathrm{~g} / \mathrm{g}$ (dry basis), respectively. It is seen that the $\mathrm{m}_{\mathrm{o}}$ value obtained from the GAB equation was higher than that calculated from the BET equation. Several authors also observed a similar trend in predicting $\mathrm{m}_{\mathrm{o}}$ value using BET and GAB models. Indeed, it is well established that the GAB monolayer value is always higher than the BET monolayer value (Timmermann and Chirife, 1991). The reason for the difference between the $m_{0}$ values obtained from these two equations had been discussed by Timmermann et al., (2001) and Quirijns et al., (2005). Lomauro et al., (1985) reported that the $\mathrm{m}_{\mathrm{o}}$ values of starchy foods generally ranged from 0.032 to $0.160 \mathrm{~g} / \mathrm{g}$ (dry basis). The energy constant $\mathrm{C}$ by BET is known to be higher than the $C$ from the GAB model. In this study, $C$ by BET model $(10.45 \mathrm{cal} / \mathrm{g}-\mathrm{mol})$ was higher than that of $\mathrm{C}$ by GAB model $(4.64 \mathrm{cal} / \mathrm{g}-\mathrm{mol})$. The data obtained were fitted to BET and GAB models for corn. The coefficient of determination $\left(\mathrm{R}^{2}\right)$ and regression sum of square for BET model was 0.995 and 0.003 , respectively. The coefficient of determination $\left(\mathrm{R}^{2}\right)$ and regression sum of square was also determined for GAB model and the corresponding value was 0.919 and 0.015 .

Table 2. Constants and coefficient for BET and GAB equations

\begin{tabular}{cccccccc}
\hline $\begin{array}{c}\text { Stability } \\
\text { model }\end{array}$ & $\begin{array}{c}\text { Monolayer moisture } \\
\text { content }\left(\mathrm{m}_{0}\right)\end{array}$ & $\begin{array}{c}\text { Constant } \\
(\mathrm{C})\end{array}$ & $\alpha$ & $\beta$ & $\gamma$ & $\mathrm{R}^{2}$ & $\begin{array}{c}\text { Regression sum of } \\
\text { square (SSR) }\end{array}$ \\
\hline BET & 6.76 & 10.45 & -- & -- & -- & 0.995 & 0.003 \\
GAB & 10.53 & 4.64 & 0.0258 & -0.0138 & 0.042 & 0.919 & 0.015 \\
\hline
\end{tabular}

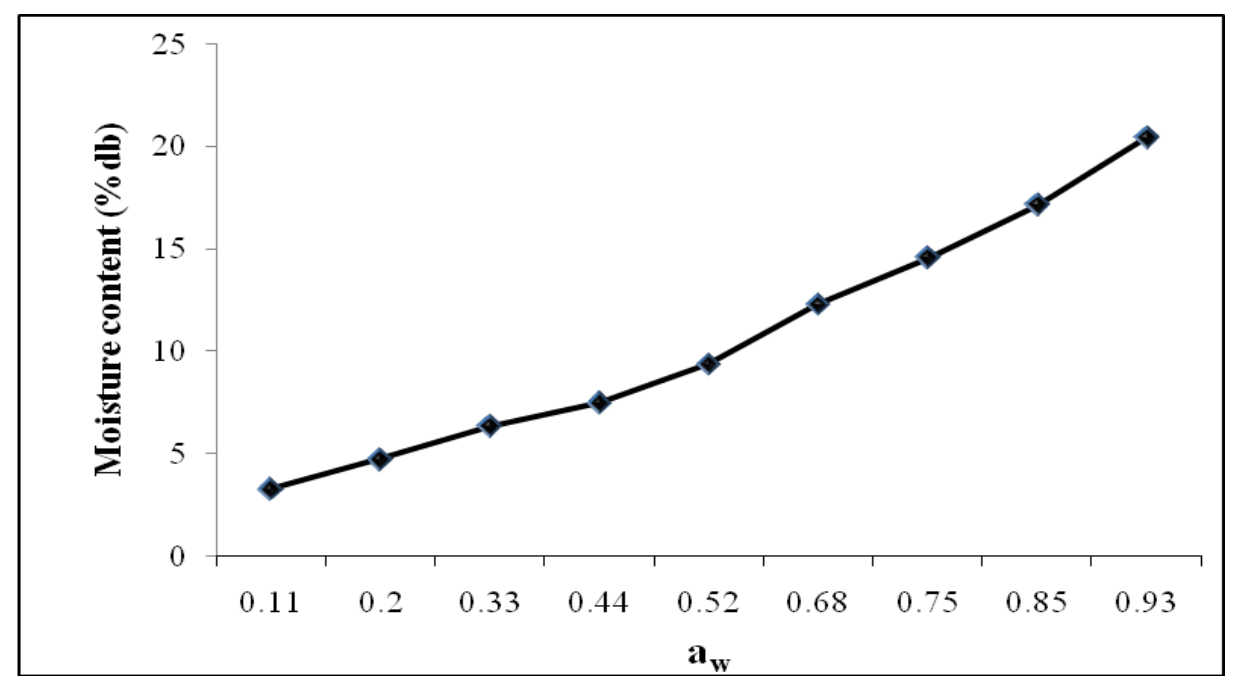

Fig. 1. Graphical presentation of sorption isotherm of corn 

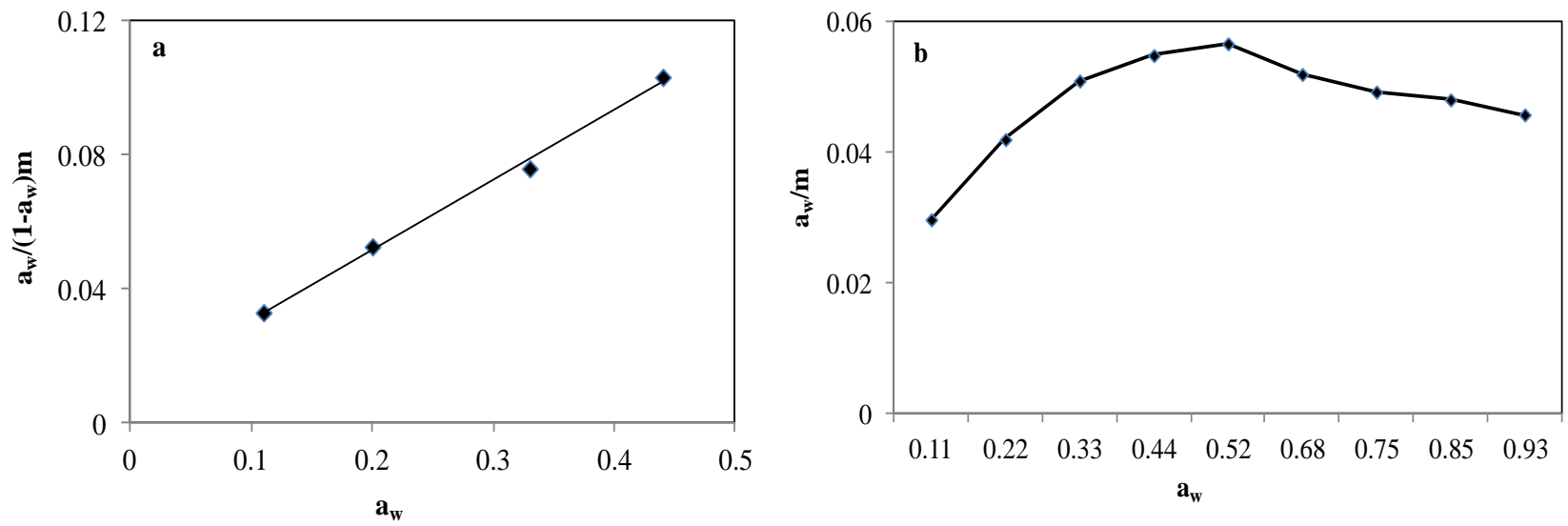

Fig. 2. Graphical presentation of (a) BET equation and (b) GAB model for sorption isotherm of corn

\section{Effect of temperature on drying time}

Corn was dried in a single layer at three different air dry bulb temperatures $\left(40^{\circ} \mathrm{C}, 50^{\circ} \mathrm{C}\right.$ and $\left.60^{\circ} \mathrm{C}\right)$ to determine the influence of temperature on drying time using constant loading density $\left(3.56 \mathrm{~kg} / \mathrm{m}^{2}\right)$ at constant air velocity $(0.6 \mathrm{~m} / \mathrm{s})$ in a cabinet dryer. The regression equations developed are as follows:

$$
\begin{aligned}
& \text { MR }=0.989 \mathrm{e}^{-0.10 \mathrm{t}} \text { at } 40^{\circ} \mathrm{C} \\
& \text { MR }=0.986 \mathrm{e}^{-0.13 \mathrm{t}} \text { at } 50^{\circ} \mathrm{C} \\
& \text { MR }=0.954 \mathrm{e}^{-0.17 \mathrm{t}} \text { at } 60^{\circ} \mathrm{C}
\end{aligned}
$$

where $\mathrm{MR}=$ moisture ratio, $\mathrm{t}=$ time in hour

From Fig. 3 and Equations 8 to 10 , it is seen that the moisture ratio (MR) (hence moisture content) decreases with time and increasing temperature. It is also observed that when temperature of dryer is increased, drying rate constant is also increased and consequently higher temperature results in faster drying rate. At very high temperature and low humidity, the drying rate may initially increase, but as drying time passes resultant case hardening would reduce drying rate and the quality of the product will be deteriorated due to cooking instead of drying. By putting MR value $=0.13$ in the above equations, it is seen that for removal of $87 \%$ moisture, i.e. to make shelf stable corn products, corn should be dried for 20, 15 and 11 hours in mechanical dryer at $40^{\circ} \mathrm{C}, 50^{\circ} \mathrm{C}$ and $60^{\circ} \mathrm{C}$, respectively. An important observation was found that when corn was dried at 60 ${ }^{\circ} \mathrm{C}$, its viability was lost very quickly.

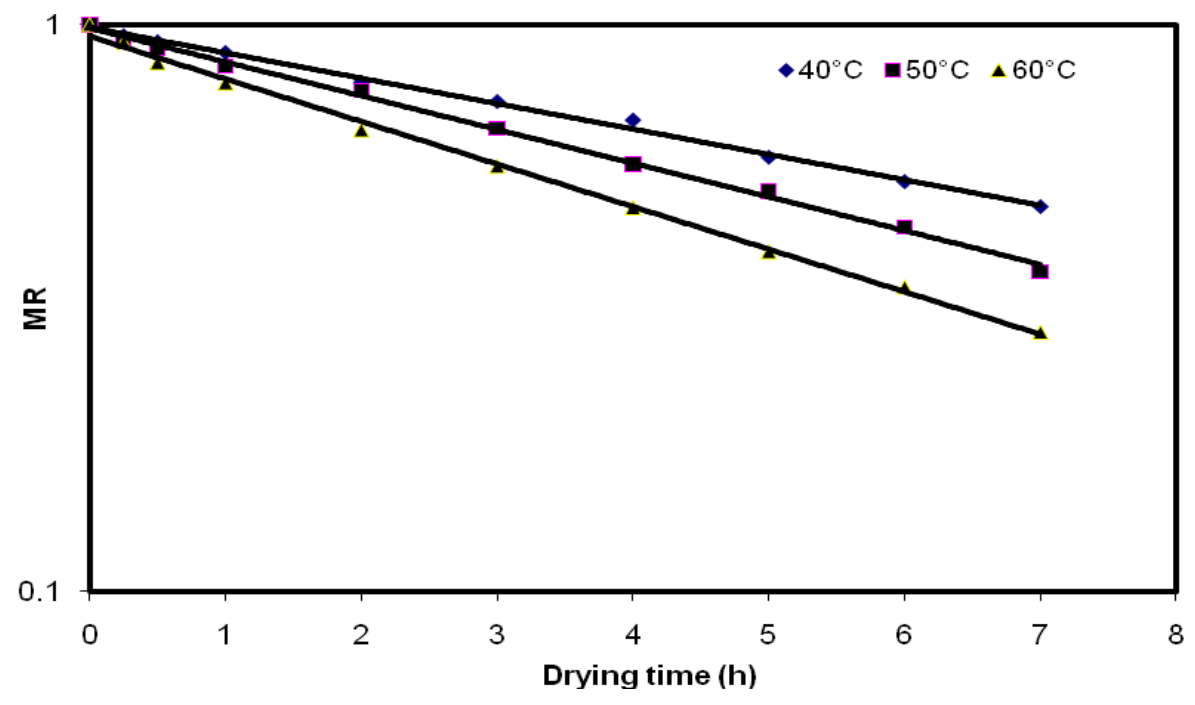

Fig. 3. Effect of temperature on drying rate for corn at constant loading density 


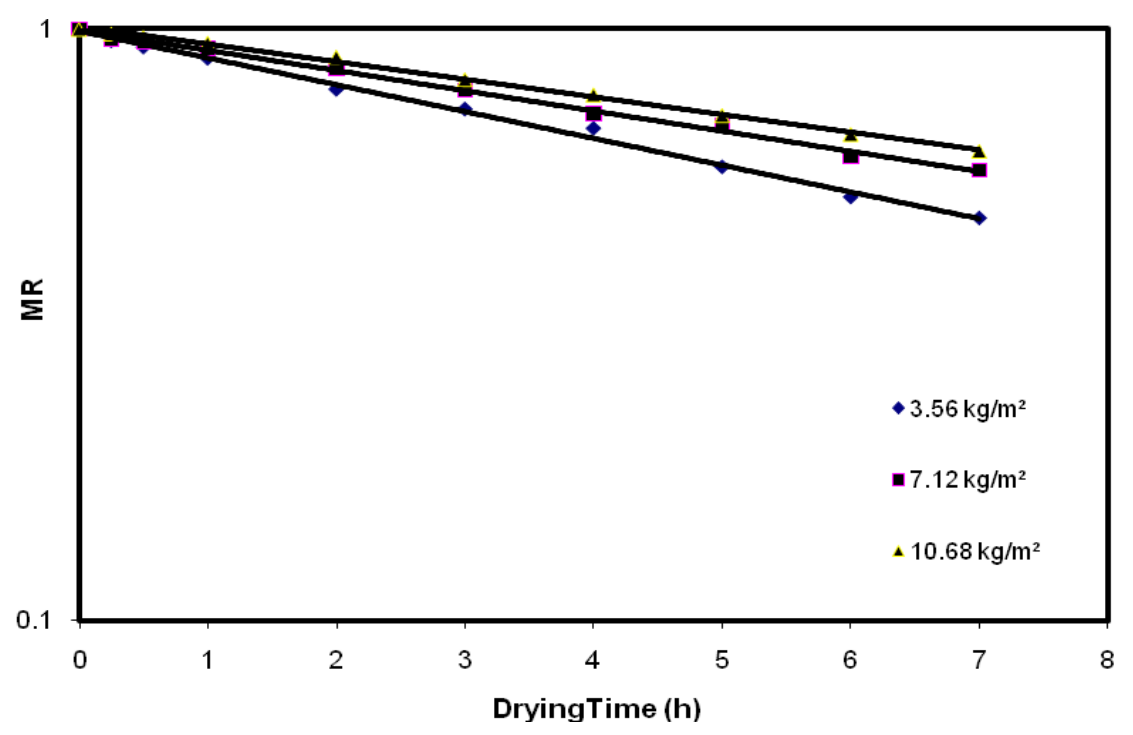

Fig. 4. Effect of loading density on mechanical drying behavior of corn at $60^{\circ} \mathrm{C}$

Effect of loading density (layer) on drying behavior of corn at various temperatures

Corn was dried at three different temperatures of $40^{\circ} \mathrm{C}$, $50^{\circ} \mathrm{C}$ and $60^{\circ} \mathrm{C}$ to study the influence of loading density $\left(3.56 \mathrm{~kg} / \mathrm{m}^{2}, 7.12 \mathrm{~kg} / \mathrm{m}^{2}\right.$ and $\left.10.68 \mathrm{~kg} / \mathrm{m}^{2}\right)$ on drying rate at constant air velocity $(0.6 \mathrm{~m} / \mathrm{s})$ in a cabinet dryer. The developed equations for corn are:

$\mathrm{MR}=0.990 \mathrm{e}^{-0.10 \mathrm{t}}$ at $40^{\circ} \mathrm{C} \quad---3.56 \mathrm{~kg} / \mathrm{m}^{2}$

MR $=0.994 \mathrm{e}^{-0.07 \mathrm{t}}$ at $40^{\circ} \mathrm{C}---7.12 \mathrm{~kg} / \mathrm{m}^{2}$

MR $=1.008 \mathrm{e}^{-0.06 \mathrm{t}}$ at $40^{\circ} \mathrm{C}---10.68 \mathrm{~kg} / \mathrm{m}^{2}$

MR $=0.983 \mathrm{e}^{-0.11 \mathrm{t}}$ at $50^{\circ} \mathrm{C}---3.56 \mathrm{~kg} / \mathrm{m}^{2}$

MR $=0.990 \mathrm{e}^{-0.08 \mathrm{t}}$ at $50^{\circ} \mathrm{C}--7.12 \mathrm{~kg} / \mathrm{m}^{2}$.

MR $=0.979 \mathrm{e}^{-0.09 t}$ at $50^{\circ} \mathrm{C}--10.68 \mathrm{~kg} / \mathrm{m}^{2}$

$\mathrm{MR}=0.964 \mathrm{e}^{-0.18 \mathrm{t}}$ at $60^{\circ} \mathrm{C}---3.56 \mathrm{~kg} / \mathrm{m}^{2}$.

MR $=0.992 \mathrm{e}^{-0.16 \mathrm{t}}$ at $60^{\circ} \mathrm{C}---7.12 \mathrm{~kg} / \mathrm{m}^{2}$

MR $=0.997 \mathrm{e}^{-0.13 \mathrm{t}}$ at $60^{\circ} \mathrm{C}---10.68 \mathrm{~kg} / \mathrm{m}^{2}$

From Fig. 4 and Equations 11 to 19, it is seen that as loading density (layer) of corn increases, the rate of drying decreases at constant temperature. But, drying rate constant (equations 11 to 19) does not decrease proportionally as loading density of corn increases (with only one exception at $50{ }^{\circ} \mathrm{C}$ ). For instance, using 3.56 $\mathrm{kg} / \mathrm{m}^{2}$ loading density, the rate constant was $0.18 / \mathrm{hr}$ at $60^{\circ} \mathrm{C}$, whereas for twice the loading density at similar condition the rate constant was $0.16 / \mathrm{hr}$. Similar results were observed for $40^{\circ}$ and $50^{\circ} \mathrm{C}$ at different loading densities.
Effect of temperature on diffusion co-efficient of corn From the MR and drying time relationship, the drying rate constants were determined for corn dried in single layer $\left(3.56 \mathrm{~kg} / \mathrm{m}^{2}\right)$ at $40^{\circ} \mathrm{C}, 50^{\circ} \mathrm{C}$ and $60^{\circ} \mathrm{C}$ air dry bulb temperature using regression analysis. From drying rate constants, diffusion coefficients were determined and plotted against inverse absolute temperature on semi-log coordinate. The regression line was drawn in Fig.5. From Fig. 5, the Arrhenius type equation is written as:

$\mathbf{D}_{e}=36.679 \mathrm{e}^{-5583.6} \mathrm{~T}_{\mathbf{a b s}}^{-1}$

where $D_{e}=$ diffusion coefficient $\left(\mathrm{cm}^{2} / \mathrm{s}\right), T_{a b s}=$ absolute temperature $\left({ }^{\circ} \mathrm{K}\right)$

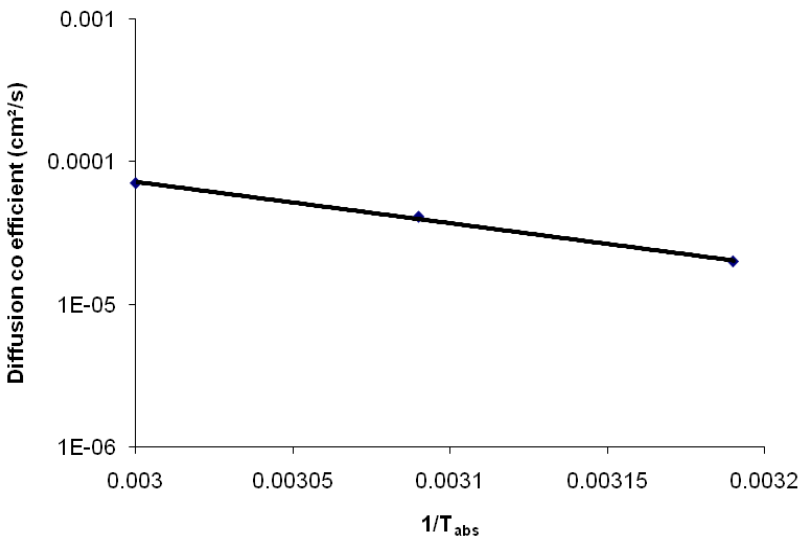

Fig. 5. Effect of temperature on diffusion coefficient 


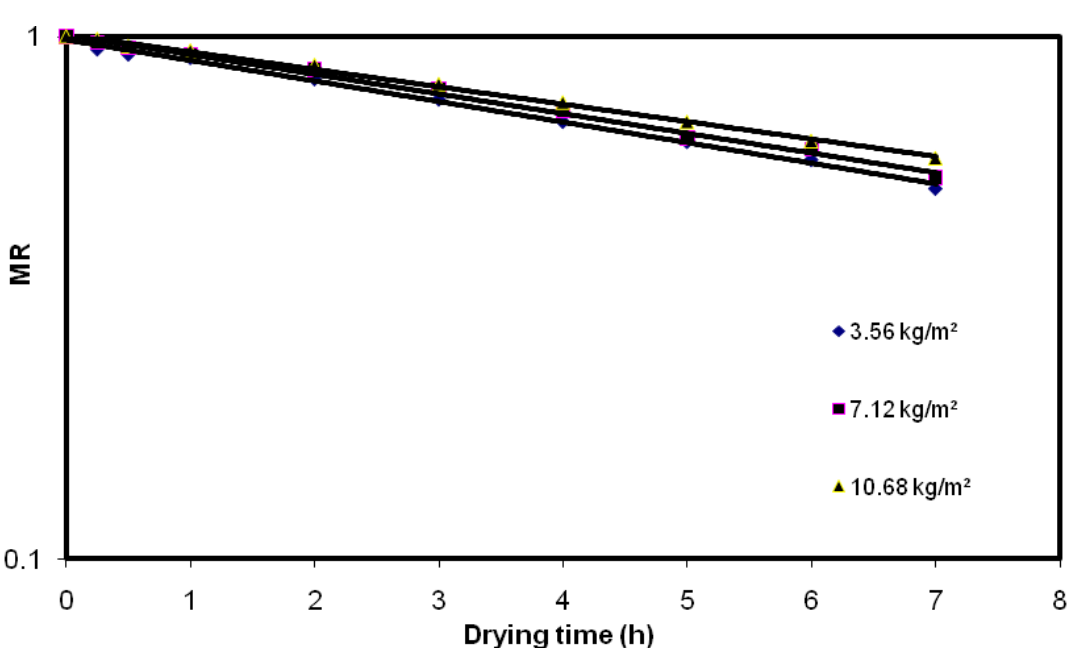

Roy et al.

Fig. 6. Effect of loading density on sun drying behavior of corn

From the slope of the resultant straight line, activation energy $\left(E_{a}\right)$ for diffusion of water was calculated and found to be $11.09 \mathrm{kcal} / \mathrm{gm}$-mole for corn. The activation energy obtained was lower than $13.8 \mathrm{kcal} / \mathrm{gm}$-mole, which was found by Pabis and Henderson (1961) for corn but higher than the $27.61 \mathrm{~kJ} / \mathrm{kg}$ mol for corn drying (Tolaba and Suarez, 1988).

Sun drying behavior and effect of loading density (layer) on sun drying behavior of corn

When the sun was shining, corn was dried on tray and kept outside to observe the sun drying behavior of corn samples with single, double and triple layer. The data are depicted in Fig. 6 and the equations were developed as follows:

$$
\begin{aligned}
& \text { MR }=0.986 \mathrm{e}^{-0.09 \mathrm{t}}----3.56 \mathrm{~kg} / \mathrm{m}^{2} \\
& \text { MR }=1.007 \mathrm{e}^{-0.08 \mathrm{t}}-----7.12 \mathrm{~kg} / \mathrm{m}^{2} \\
& \text { MR }=1.009 \mathrm{e}^{-0.07 \mathrm{t}}
\end{aligned}
$$

From Fig. 6 and Equations 21 to 23, it was seen that as layer of corn increases, the rate of drying decreases. Drying rate constant also decrease as layer of corn increases. For example, sun drying of corn using 3.56 $\mathrm{kg} / \mathrm{m}^{2}$, the rate constant was $0.09 / \mathrm{h}$ and at loading density $7.12 \mathrm{~kg} / \mathrm{m}^{2}$, the rate constant was $0.08 \mathrm{~h}$; whereas, at loading density $10.68 \mathrm{~kg} / \mathrm{m}^{2}$, the rate constant was $0.07 \mathrm{~h}$. Kamruzzaman (2005) and Islam (1980) also made similar observation. Drying rate was relatively low and for removing $87 \%$ moisture, corn should be dried for 22, 25 and 29 hours in open sun at single, double and triple layer, respectively.

\section{End-point drying time of corn to achieve stability}

The BET and GAB models are generally recognized as the best models (Singh and Heldman, 1993). Moisture content in equilibrium with $0.65 \mathrm{a}_{\mathrm{w}}$ has been recognized as the stable moisture content of food product (Nickerson and Sinskey, 1977). The calculated drying time as per Equations 8-23 at different drying conditions are given in Table 3.

From Table 3, it is seen that the highest drying time (16 h) was required for triple layer for BET model $(6.76 \%$ $\mathrm{mc} \mathrm{db})$ at $40^{\circ} \mathrm{C}$ and the lowest time $(2.4 \mathrm{~h})$ was required for single layer at $60^{\circ} \mathrm{C}(12.08 \% \mathrm{mc}$. d.b. at $0.65 \mathrm{a}_{\mathrm{w}}$ ). At constant temperature (drying conditions), drying time to obtain stability was the lowest for moisture content $12.08 \%$ correspond to $a_{w} 0.65$ compared to either BET or GAB monolayer moisture content. It is also seen that at constant drying conditions (temperature, humidity, etc,) and for a given model (BET, GAB, $a_{w}$ ), higher loading density results in more efficient drying, i.e., more product dried at a given time. In case of drying at $60^{\circ} \mathrm{C}$, it is very tough to grind the corn for producing further products. Thus, corn drying at $50^{\circ} \mathrm{C}$ gives better particle size, and can be conveniently used for milling and baking industry. 
Table 3. Variation of end-point drying time (h) at different drying conditions and stability model

\begin{tabular}{|c|c|c|c|c|}
\hline \multirow{2}{*}{$\begin{array}{c}\text { Temperature } \\
{ }^{\circ} \mathrm{C}\end{array}$} & \multirow{2}{*}{ Layer } & \multicolumn{3}{|c|}{ Drying time } \\
\hline & & BET & GAB & At $a_{w}=0.65$ \\
\hline \multirow[t]{3}{*}{$40^{\circ} \mathrm{C}$} & SL & 9.6 & 5.9 & 4.3 \\
\hline & DL & 13.7 & 8.4 & 6.1 \\
\hline & $\mathrm{TL}$ & 16.0 & 9.8 & 7.2 \\
\hline \multirow[t]{3}{*}{$50^{\circ} \mathrm{C}$} & SL & 8.7 & 5.4 & 3.9 \\
\hline & DL & 12.0 & 7.4 & 5.4 \\
\hline & $\mathrm{TL}$ & 10.7 & 6.6 & 4.8 \\
\hline \multirow[t]{3}{*}{$60^{\circ} \mathrm{C}$} & SL & 5.3 & 3.3 & 2.4 \\
\hline & DL & 6.0 & 3.7 & 2.7 \\
\hline & $\mathrm{TL}$ & 7.3 & 4.5 & 3.3 \\
\hline \multirow[t]{3}{*}{ Sun Drying } & SL & 10.7 & 6.6 & 4.8 \\
\hline & DL & 12.0 & 7.4 & 5.4 \\
\hline & $\mathrm{TL}$ & 13.7 & 8.4 & 6.1 \\
\hline
\end{tabular}

$\mathrm{SL}=$ Single layer (loading density, $3.56 \mathrm{~kg} / \mathrm{m}^{2}$ ); DL= Double layer (loading density, $7.12 \mathrm{~kg} / \mathrm{m}^{2}$ ) and TL= Triple layer (loading density, $10.68 \mathrm{~kg} / \mathrm{m}^{2}$ )

\section{Conclusion}

It is a big challenge to ensure quality storage of agro products because of high moisture content. To address the issue it can be concentrated on drying that enriches maize with the longest storage capacity. Fick's law of diffusion for thin layer drying could be used to model drying characteristics of corn. The drying rate, as expected, increases with the increase of drying air temperature, but decreases with loading density. Moisture sorption isotherms serve as a blueprint for moisture relations in food products. The monolayer moisture content of corn calculated by the BET and $\mathrm{GAB}$ equations was found to be $0.0676 \mathrm{~g} / \mathrm{g}$ (dry basis) and $0.1059 \mathrm{~g} / \mathrm{g}$ (dry basis), respectively, indicating the optimal moisture for maximum storage stability in the dry state. Study about the equilibrium moisture content will prevent over-drying and thus decrease drying time, energy cost, mass losses and the risk of quality deterioration. At constant temperature (drying conditions), drying time to obtain stability was the lowest for moisture content $(12.08 \%)$ correspond to $\mathrm{a}_{\mathrm{w}}$ 0.65 compared to either BET or GAB monolayer moisture content. Then corn drying at $50^{\circ} \mathrm{C}$ gives better particle size and can be conveniently used for milling and baking industry. Further research should be undertaken using different drying and sorption models to completely characterize the drying and storage behavior of corn.

\section{Acknowledgements}

The authors convey gratefulness to NST authority as the research was provided with immense support by a research fellowship from NST (National Science and Technology), Ministry of Science and Technology, Government of the People's Republic of Bangladesh.

\section{References}

Al-Muhtaseb, A.H., Mcminn, W.A.M. and Magee, T.R.A. 2002. Moisture sorption isotherm characteristics of food products: a review. Institution of Chemical Engineers Transactions, 80: $118-128$.

Anderson, R.B. 1946. Modification of the Brunauer, Emmett and Teller equation. Journal of the American Chemical Society, 68: 686-691.

Bizot, H. 1983. Using the GAB model to construct sorption isotherms in "Physical Properties of Foods". pp. 43-54. Applied Science Publishers, London.

Boquet, R., Chirife, J. and Iglesias, H.A. 1978. Equations for fitting water sorption isotherms of foods. International Journal of Food Science \& Technology, 13(4): 319-327.

Brooker, D.B., Bakker-Arkema, F.W. and Hall, C.W. 1992. Drying and storage of grains and oilseeds. Springer Science \& Business Media.

Brunauer, S., Emmett, P. H. and Telller, E. 1938. Adsorption of gases in multimolecular layers. Journal of the American Chemical Society, 60: 309-319.

Chen, C. and Weng, Yu-Kai. 2010. Moisture Sorption Isotherms of Oolong Tea. Food Bioprocess Technology, 3: 226-233.

Crank, J. 1975. The Mathematics of Diffusion: 2d Ed. Clarendon Press.

De Boer, J.H. 1953. The Dynamic Character of Adsorption. pp. 61-81. Oxford: Clarendon Press.

Doymaz, I and Pala, M. 2003. The thin-layer drying characteristics of corn. Journal of Food Engineering, 60: 125-130.

Gokhan, B., Bhagwati, P. and Zhongli, P. 2012. Dynamic vapor sorption isotherms of medium grain rice varieties. LWT Food Science and Technology, 48:156-163.

Gopalan, C., Sastri, B.V.R. and Balasubramanian, S.C. 1981. Nutritive value of Indian foods. National Institute of Nutrition. ICMR, Hyderabad, India.

Guggenheim, E. A. 1966. Application of Statistical Mechanics. pp. 186-206. Oxford: Clarendon Press.

Islam, M. N. 1980. Use of solar energy for development of shelf-stable potato product. Ph.D. Thesis, Royal Veterinary and Agriculture University, Copenhagen, Denmark.

Jyoti, H. and Takhar, P. S. 2010. Experimental study on the effect of glass transition on moisture profiles and stress-crack formation during continuous and time-varying drying of maize kernels. Biosystems Engineering, 106: 156 -165.

Kamruzzaman, M. 2005. Development of Dehydrated Aroids (Colocasia esculenta) Product by using mechanical and indirect solar dryer. Unpublished M.S. Thesis, Department of Food Technology and Rural Industries, Bangladesh Agricultural University, Mymensingh. 
Kaymak-Ertekin, F. and Gedik, A. 2004. Sorption isotherms and isosteric heat of sorption for grapes, apricots, apples and potatoes. LWT-Food Science and Technology, 37(4): 429438.

Kim, S. and Dale, B.E. 2004. Global potential bioethanol production from wasted crops and crop residues. Biomass and Bioenergy, 26: 361-375.

Labuza, T.P. 1975. Sorption Phenomena in Foods: Theoretical and Practical Aspects. In: Rha C. (eds) Theory, Determination and Control of Physical Properties of Food Materials. Springer Netherlands. pp 197-219.

Lomauro, C.J., Bakshi, A.S. and Labuza, T.P. 1985. Evaluation of food moisture sorption isotherm equations. Part I: Fruit, vegetable and meat products. Lebensmittel-Wissenschaft and Technologie, 18(2): 111-117.

McMinn, W.A.M. and Magee, T.R.A. 2003. Thermodynamic properties of moisture sorption of potato. Journal of Food Engineering, 60, 157-165

Nickerson, J.J.R. and Sinskey, A.J. 1977. Microbiology Foods and Food Processing, Elsevier North Holland, Inc. 52 Vanderbilt Avenue, New York.

Pabis, S., and Henderson, S.M. 1961. Grain-drying theory: II. A critical analysis of the drying curve for shelled maize. Journal of Agricultural Engineering Research, 6(4): 272-277.

Quirijns, E.J., Van Boxtel, A.J., van Loon, W.K. and Van Straten, G. 2005. Sorption isotherms, GAB parameters and isosteric heat of sorption. Journal of the Science of Food and Agriculture, 85(11): 1805-1814.
Rahman, M.S. and Sablani, S.S. 2009. Food Properties Handbook, Second Edition. CRC Press, Taylor and Francis Group. pp. 9-31.

Saravacos, G.D. and Raouzeos, G.S. 1986. Diffusivity of moisture in air-drying of raisins. Drying, 86.2 : 487-491.

Singh, P. and Heldman, D.R. 1993. Introduction to Food Engineering. $2^{\text {nd }}$ Edition. Elsevier Science Publishing Co Inc. pp 417419.

Staudt, P.B., Tessaro, I.C., Marczak, L.D.F., Soares, R. de P. and Cardozo, N.S.M. 2013. A new method for predicting sorption isotherms at different temperatures: Extension to the GAB model. Journal of Food Engineering, 118: 247255.

Timmermann, E.O. and Chirife, J. 1991. The physical state of water sorbed at high activities in starch in terms of the GAB sorption equation. Journal of Food Engineering, 13:171179.

Timmermann, E.O., Chirife, J. and Iglesias, H.I. 2001. Water sorption isotherms of foods and foodstuffs: BET or GAB parameters? Journal of Food Engineering, 48: 19-31.

Timmermann, E.O. 2003. Multilayer sorption parameters: BET or GAB values? Colloids and Surfaces A: Physicochemical and Engineering Aspects, 220(1): 235-260.

Tolaba, M.P. and Suarez, C. 1988. Simulation of the thin-layer drying of corn by means of the diffusional model. LebensmittelWissenschaft and Technologie, 21(2): 83-86. 